\title{
Enhancing cooperation between HEIs and Companies in South East Asia to accelerate sustainable business opportunities
}

\author{
Martijn Rietbergen ${ }^{1}$, Erlijn Eweg ${ }^{2}$ \\ ${ }^{1,2}$ Research Center Healthy and Sustainable Living, University of Applied Science Utrecht, \\ The Netherlands
}

\begin{abstract}
This proposed project builds forth on the still ongoing ERASMUS+ capacity building project "Sustainability Alliance of Urban Networks in Asian Cities" (SAUNAC). SAUNAC, amongst others, aimed at designing, implementing and evaluating educational programs on Smart Sustainable Cities at Vietnamese universities. This new proposed project takes SAUNAC to a next level, by further developing the cooperation in the quadruple helix, especially between Higher Education Institutes on the one hand and Companies active in Vietnam on the other hand. This requires additional efforts to tuning of (degree) programmes with competences required by businesses. The target group of companies / HEIs are active in the field of sustainable development.
\end{abstract}

Keywords: Funding: Erasmus+ Capacity Building. 
Enhancing cooperation between HEIs and Companies in South East Asia to accelerate sustainable business opportunities

\section{Introduction}

The past three years the CARPE consortium (led by the Turku University of Applied Science) run the ERASMUS+ capacity building project "Sustainability Alliance of Urban Networks in Asian Cities" (SAUNAC). SAUNAC, amongst others, aimed at designing, implementing and evaluating educational programs on Smart Sustainable Cities at Vietnamese universities. Since the SAUNAC project is coming to an end soon, we should think about further exploiting the results of the project: meaningful impacts have been achieved if it comes to an active learning approach, an intensive network with a wide a variety of stakeholders has been developed, and an integrated approach to urban sustainable development has been preached. In addition, a wide range of opportunities for a potential follow-up project have been brought up. This paper briefly introduces the SAUNAC project (section 2), identifies opportunities, topics or ideas for a follow-up project (section 3), proposes a potential source of funding (section 4), and finalizes with a wrap up (section 5).

\section{The project "Sustainability Alliance of Urban Networks in Asian Cities"}

This document could be used as a template for formatting the papers. All texts, figures and tables must be included within the document margins.

\subsection{SAUNAC consortium}

Sustainability Alliance of Urban Networks in Asian Cities (SAUNAC) is an ERASMUS+ KA2 Capacity Building project running from 2016 - 2019. The project is a collaboration between higher education institutions from Europe and Vietnam. The European partner Universities include the following members of the Consortium on Applied Research and Professional Education (CARPE): Turku University of Applied Sciences (Finland), University of Applied Science Utrecht (Netherlands), the Universitat Politècnica de València (Spain), Manchester Metropolitan University (UK), and the Hamburg University of Applied Sciences (Germany). The partner Universities in Vietnam are the Hanoi University of Civil Engineering, the Danang University of Science and Technology, the Ho Chi Minh City University of Natural Resources and Environment, the Vietnam National University, the Haiphong University, and the Hue University of Sciences. 


\subsection{SAUNAC project goals}

The SAUNAC project focuses on the following objectives: 1) accelerating the design, development and acceptance of viable solutions for sustainable cities in Vietnam;2) the development of a joint course on the design of sustainable cities in Vietnam; 3) the exchange of best practices of innovative educational approaches; and 4) the strengthening of the triple helix network in Vietnam.

\subsection{Main activities in the SAUNAC project}

A wide range of activities have been carried in the SAUNAC project. First of all a couple of train-the-trainer sessions have been carried to learn Vietnamese teacher how to use active learning methods, blended learning techniques and co-design techniques in their education. Second, much efforts were put in designing modules on various topics on Smart Sustainable Cities in a Vietnamese context. Third, these modules were piloted at different universities. The applied research projects for students was considered as highlight that condensed many aspects of the SAUNAC project. Fourth, a couple of conferences were organized to disseminate the results of the project. Fifth, stakeholder engagement was a central theme as well the enhance the cooperation between partners in the triple helix. Sixth, the project also focused on further exploitation of project results, e.g. developing further cooperation between involved project partners.

\section{Future Challenges}

Based on the experiences in the SAUNAC project we identify a couple of opportunities, ideas or topics that a follow up project could focus on. These topics are 'Increasing impact by introducing Leadership training', 'Triple Helix cooperation', 'increased mutual benefits' and 'Corporate Social Responsibility'.

\subsection{Increasing impact by introducing Leadership training}

Based on earlier experience in the SAUNAC project, we identified an implicit need to introduce some sort of leadership training (or similar type of ideas, such as champions within university, ambassadors for change, change agents, etc.) that could facilitate 'change' for modernization of the educational system more effectively. As Knuutila \& Lappalainen (2018) stated, the educational system is modernizing slowly; 'a transformation from a hierarchic teacher-centered learning culture towards student-centered learning takes time'. Therefore, there is a need for forerunners. The concept of 'Leadership in the classroom, in school and in the community', by 'Teach for Vietnam' initiative, is an interesting approach that we could built upon in a future project. 
Enhancing cooperation between HEIs and Companies in South East Asia to accelerate sustainable business opportunities

\subsection{Triple Helix cooperation}

The triple helix of innovation-driven economic growth conceptualizes the cooperation between universities, governments and industries. Universities have a pivotal role in driving innovation. Despite small steps have been made to enhance cooperation in this triple helix, universities are still often acting traditionally (communicating knowledge) rather than teaching critical thinking, promoting entrepreneurial skills and getting engaged in demand driven activities (Baark, 2016). Furthermore, companies could play a much important role in modernizing education, e.g. helping to introduce competence based education, doing applied research, providing internship opportunities, etc. Governments should play a facilitating role in innovation, e.g. by providing the right policies, measures and laws. The quadruple helix module is an extension of the triple helix model in which citizens, local communities or societal interest groups are also added. Since the role of consumers (users) is critical in the development of Smart Sustainable Cities, we suggest to use quadruple helix model in future projects.

\subsection{Increased mutual benefits}

A long term cooperation between European and Vietnamese universities will only last if there are mutual benefits. Up till now, the benefits for European partners are primarily related to extending their project portfolio to Asia, increasing their network with Vietnamese universities, promoting their research and educational activities abroad. For the longer term it is very important that European partners should utilize these type of projects better, e.g. for acquiring funded research projects, enhanced student exchange and supporting local / regional European companies with accelerating their business opportunities in Vietnam. Therefore, the involvement of local European companies in a future project might add value significantly, both for student, university and company.

\subsection{Corporate Social Responsibility / Sustainable growth}

The concept of corporate social responsibility (CSR) has been implemented widely among firms in Europe. CSR means that the company has procedures in place of that balances the impact of its business activities on people, the environment and their business operations. According to Phan Van Thanh \& Szilárd Podruzsik (2018) the implementation of the CSR concept in Vietnam is still limited. In a developing country like Vietnam, it is however of great interest that companies in order to grow sustainably, should adhere to the sustainable development principles like environmental protection, equality, inclusiveness, safety, talent management, community growth etc. 


\section{Realizing new ideas}

One of the potential sources of funding is the ERASMUS+ Key Action 2 on Capacity Building in the field of Higher Education (CBHE), see EC (2019). The CBHE promote cooperation and partnerships that have an impact on the modernization and internationalization of higher education institutions and systems in Partner Countries, such as Vietnam. Projects have a typical size of around 900.000 euros. The budget for CBHE in Region 6 countries (including Vietnam) was around 48 million in 2018. One of the defined priority theme in Asia region 6 is the cooperation between Higher Education Institutes and Business.

\section{Wrap-up}

The SAUNAC ERASMUS+ KA2 Capacity Building project is a collaboration between higher education institutions from Europe and Vietnam. It primarily aims at designing, implementing and evaluating educational programs on Smart Sustainable Cities at Vietnamese universities. A wide range of opportunities arise to further exploit the results of this project. A future project could combine a set of various topics that have been identified such as 1) increasing the mutual benefits (by increasing the role of European companies in the project); 2) further intensification of cooperation in the triple helix; 3) develop leadership trainings; 4) corporate social responsibility / smart sustainable cities. The central theme of a future project could be 'enhancing the cooperation between HEIs and Companies in South East Asia to accelerate sustainable business opportunities modernizing (degree) programmes'. At the conference we would like to discuss these opportunities in more detail, identify additional ideas, exchange experiences on working in Asian countries, and investigate future cooperation.

\section{References}

Rietbergen, M.G., E. De la Poza, J. Orozco-Messana (2018). Designing a programme for Sustainability in Vietnam: Smart Sustainable Vietnamese Cities, SSVC. 4th International Conference on Higher Education Advances (HEAd'18) Universitat Politecnica de Valencia, Valencia, 2018.

EC (2019). Erasmus+ Programme Guide - version 2 2019. European Commission

Lehmann, S., F. Schubert, I. Herrmann, P Vuthi (2017). Sustainability Alliance of Urban Networks in Asian Cities (SAUNAC) - a Project Overview. Fakultät Technik und Informatik Department Informations- und Elektrotechnik - E-Forum. 
Enhancing cooperation between HEIs and Companies in South East Asia to accelerate sustainable business opportunities

Le Hieu Hoc, (2019). University-Industry Linkages in Promoting Technology Transfer: A Study of Vietnamese Technical and Engineering Universities. Science, technology and Society 23(1), 73-100.

Baark, E. (2016). Innovation System Reform in Indonesia and Vietnam: A New Role for Universities? Journal of STI Policy and Management 1(1) 1-15.

Knuutila, H., H. Lappilainen (2018). Modernizing Vietnamese sustainable development education - case study of SAUNAC project. Paper presented at the conference on 'scientific and management solution for effective use of natural resources and energy towards sustainable development and climate change adaptation'. 29 November 2018, Ho Chi Min City, Vietnam.

Phan Van Thanh, Szilárd Podruzsik (2018). CSR in Developing Countries: Case Study in Vietnam. Management 13 (4): 287-300. 